\title{
ARTIKELEN
}

\section{Democratische weerbaarheid vanuit radicale openheid}

\section{Impliciete religie in extremisme én contra-extremisme*}

\author{
Saskia Tempelman
}

\begin{abstract}
'It seems to me that the moralist is the most useless and contemptible of creatures. $H e$ is useless in that he would expend his energies upon making judgments rather than upon gaining knowledge, for the reason that judgment is easy and knowledge is difficult. He is contemptible in that his judgments reflect a vision of himself which in his ignorance and pride he would impose upon the world. I implore you, do not become a moralist; you will destroy your art and your mind.'

- John Williams, Augustus
\end{abstract}

In de publieke discussie over terrorisme woedt zowel in als buiten Nederland een controverse rondom de 'echte' drijfveren van jihadisten. Is het de kwaadaardige religie of zijn 'drijvers', zoals discriminatie of werkloosheid, belangrijker? ${ }^{1}$ Beide posities roepen felle emoties op: de een vindt de ander naïef over de rol van de (politieke) islam, terwijl de ander juist vindt dat de eerste moslims stigmatiseert en hen daarmee in de armen van radicalen drijft.

Het recente proefschrift van Birgit Pfeifer over de rol van 'impliciete religie' bij zogenoemde 'school-shooters' biedt een nieuw perspectief op deze patstelling. ${ }^{2}$ De centrale these van Pfeifer is dat impliciet religieuze aspecten - existentiële vragen, behoefte aan transcendente ervaringen en zingevende rituelen - een cruciale werking hebben op het extreme geweld van school-shooters. De religieuze werking is impliciet omdat het niet gaat om een 'God' of een formele geloofsleer. Het is desondanks wel religieus te noemen, omdat de werking draait om de persoonoverstijgende krachten en ervaringen die als 'sacraal' worden beleefd.

Uit mijn ervaring met contra-extremisme herken ik deze werking van impliciete religie in de drijfveren van jihadisten, maar ook in die van andere extremisten. In het navolgende zal ik dit toelichten. Maar wat interessant is, is dat dezelfde type impliciete religieuze motieven en argumenten van extremisten terugkeren in de verhalen van degenen die zichzelf juist zien als 'bestrijders van terrorisme en extremisme'. Daar verschijnen jihadisten (en salafisten) als 'duivels' die je moet

* Dit artikel verschijnt op persoonlijke titel.

1 Illustraties zijn het werk van Gilles Kepel voor de religie-argumentatie en Olivier Roy voor de sociale.

2 E.I. Bailey, in: B. Pfeifer, School shootings: existential concerns and implicit religion, Windesheim 2017. 
uitdrijven met een 'war on terror' die soms trekjes vertoont van een heilige jihad. Ik schrik van de ongenuanceerde, kille manier waarop over vaak heel jonge mensen wordt gepraat. Demonisering en moralisme leiden tot een wederzijdse verharding die de democratische rechtsorde niet verder helpt. Deze schrik drijft me om te onderzoeken wat dan wél echte democratische weerbaarheid is. Dit artikel onderzoekt deze vraag.

\section{Impliciete religie}

Extremistisch geweld is anders dan 'gewone' criminaliteit en andere vormen van geweld. ${ }^{3}$ Dat heeft vooral te maken met de 'verhalen' die worden verteld ter rechtvaardiging voor het geweld. Verhalen waar extremisten heilig in geloven, verhalen die zin geven aan hun handelen. Maar ook extreme geweldsdaden die ogenschijnlijk niet zijn gemotiveerd door het geloof in een nieuwe wereldorde of een Heilige Oorlog, zijn omgeven met zingevingsverhalen met een 'impliciet religieuze lading' Deze verhalen zijn goed te begrijpen in religieuze termen. Niet in de gangbare zin van religie als formele geloofsleer of het aanbidden van een God, maar in de zin van wat Birgit Pfeifer omschrijft als 'implicit religion'.

Pfeifer onderzocht het verbijsterende fenomeen van 'school-shootings', waarbij relatief doorsnee jonge mannen schijnbaar uit het niets hun schoolgenoten en docenten zonder scrupules neerschieten. Pfeifer probeert deze acties te doorgronden door te luisteren naar wat 'school-shooters' zélf zeggen in hun dagboeken, correspondentie en testamenten. Daar vindt ze volop uitspraken over thema's als dood, liefde, haat, isolement. Volgens Pfeifer is deze existentiële worsteling met 'the daunting facts of life' de sleutel tot het begrijpen van de motieven voor die verschrikkelijke daden. ${ }^{4}$

In hun geschriften geven school-shooters aan dat ze zich niet geliefd, onbegrepen en buitengesloten voelen. Ze zijn vervuld met eenzaamheid en haat. Vrijheid is ook een veelvoorkomend thema: de anderen (school, samenleving) bepalen je leven. De daders fantaseren over wraak, niet alleen voor zichzelf, maar uit naam van álle vernederden. Mensen die horen bij de groep die hen kwetsten, moeten dood. De held bevrijdt zo de wereld van het kwaad.

Het is belangrijk te begrijpen, benadrukt Pfeifer, dat de geweldsdaad voor schoolshooters geen probleem is, maar juist een oplossing. Wat voor buitenstaanders zinloos geweld lijkt, is voor hen uiterst rationeel en functioneel: als heling van het gekwetste ego, als ontsnapping uit een als betekenisloos ervaren leven. De held

3 Radicalisering is de toenemende bereidheid om vanuit ideologisch motief diepingrijpende veranderingen na te streven die de democratische rechtsorde ondermijnen. Dit gaat meestal gepaard met ondemocratische middelen. Via systematisch haat zaaien, demoniseren en intimideren tot het gebruik van geweld. Het doel heiligt daarbij de middelen. Extremisme is wanneer personen of groepen bereid zijn hierbij de wet te overtreden (www.aivd.nl).

4 S.L. Koole, in: Pfeifer 2017, p. 117. Dat het zonder uitzondering over mannelijke adolescenten gaat, doet bij Pfeiffer de vraag rijzen voor welke kritieke existentiële uitdagingen jonge mannen staan in deze samenlevingen. 
ervaart in één klap vrijheid, superioriteit én betekenisvolle actie, zelfs als, of misschien juist dóórdat, hij het met de dood bekoopt.

Pfeifer analyseert deze processen in termen van het begrip 'implicit religion'. De term verwijst naar existentiële overtuigingen, transcendente verlangens en sacrale rituelen. Elk mens ervaart de behoefte om betekenis te geven aan het bestaan en aan het eigen handelen daarin. We spreken van 'impliciete religie' als mensen antwoorden op deze existentiële behoeften vinden in transcendente verhalen die het persoonlijke overstijgen. Zo plaatsen de school-shooters hun lijden in een groter verhaal, bijvoorbeeld over een systeem dat persoonlijke vrijheid onderdrukt, een systeem dat zo verrot is dat extreme actie nodig is om de vrijheid weer te herstellen.

Naast betekenisverlening heeft impliciete religie ook te maken met een verlangen om op te gaan in iets groters dan het zelf. Onalledaagse eenheidservaringen kunnen een intens gevoel van kracht, betekenis en geluk brengen. Sommigen zoeken deze ervaring in de samensmelting met een 'hogere macht' in gebed of meditatie; anderen in de natuur, in muziek of, zoals Pfeifer beschrijft, in de transgressieve ervaring van extreem geweld. De schietende jongere laat de zwakte en het lijden achter zich en gaat geheel op in het almachtige gevoel van de 'wrekende engel'.

Naast betekenisverlening en eenheidservaringen is een ander aspect van impliciete religie die van de als heilig ervaren rituelen van transformatie. Rituelen bieden structuur en houvast, vooral in tijden van crisis of bij belangrijke gebeurtenissen (sterven, ongeluk, trouwen enz.). Rituelen krijgen het karakter van impliciete religie als ze aspecten en symbolen behelzen met een als zeer bijzonder, sacraal ervaren lading. Pfeifer laat zien hoe school-shooters ceremoniële handelingen verrichten (hun lichaam trainen, een testament maken, bidden tot God) voordat ze tot hun heilige actie overgaan. Die rituelen zijn uiterst belangrijk om de gewenste transformatie van de identiteit van de schutter te begeleiden: van eenzaamheid naar verbondenheid, van onzekerheid naar trots, van chaos naar orde.

Impliciete religie biedt dus betekenis, houvast en richting. De geschriften van school-shooters laten zien hoe diep eenzaam, vernederd en leeg ze zich voelen. Deze uiterst pijnlijke gevoelens voeden een krachtig verlangen om zin in het leven te zoeken. De oplossing vinden ze in een zelfbeeld als uitverkorene en martelaar, en sommigen vergelijken zichzelf met Bijbelse figuren zoals Mozes. Geweld verschijnt steeds meer als onontkoombare ontsnappingsroute. De extreme geweldsdaad wordt uiteindelijk zowel de zin van het leven als de ultieme eenheidservaring, als een sacraal ritueel: de vijand is overwonnen, de morele orde hersteld, de 'superhero' bewezen in zijn ware goddelijke identiteit. ${ }^{5}$

Bij school-shootings komt op het eerste gezicht geen religie kijken, maar Pfeifer toont dat impliciete religie wel degelijk een cruciale rol speelt. Dit roept de vraag op hoe het speelt bij geweld dat zich nadrukkelijk wél op religie beroept. Pfeiffer beveelt aan om 'the possibility of terrorism as meaning-giving construct' verder te onderzoeken. In de volgende paragraaf pak ik deze handschoen op.

5 'Redemptive violence': de rechtvaardige held heelt de orde met gerechtvaardigd geweld - een krachtige mythe die in films e.d. eindeloos wordt herhaald. Pfeifer 2017, p. 119. 


\section{Impliciete religie en extremisme?}

In hoeverre spelen de aspecten van existentiële verhalen, transcendente ervaringen en sacrale rituelen een rol bij radicalisering richting extremisme? De gedachte van radicalisering als 'betekenisverlenend construct' is niet nieuw. ${ }^{6}$ Hoe existentiele behoeften spelen bij radicalisering is onlangs verder uitgediept in een onderzoek onder de titel Formers and Families. In dit onderzoek werden in drie landen de processen van radicalisering én de-radicalisering van dertig extremisten (zowel links-, rechts- als moslim-extremisten) onderzocht op basis van diepte-interviews met deze voormalig extremisten en hun familieleden. ${ }^{7}$ De onderzoekers beschrijven het proces van radicalisering als een ontsporing van identiteitsontwikkeling. Vooral bij adolescenten hebben existentiële vragen en gevoelens rondom dood, eenzaamheid en identiteit vaak een extreem urgent karakter. Deze worsteling kan ontsporen als die niet goed wordt begeleid door ouders of andere volwassenen in de omgeving.

De onderzoekers gaan er niet als zodanig op in, maar het is interessant om de werking van impliciete religie te leggen langs de drie hoofdroutes naar radicalisering die zij onderscheiden. Deze routes beschrijven veelvoorkomende kenmerken van de processen die personen doorlopen, zowel bij toetreding tot (radicalisering) als bij het verlaten van de extremistische beweging (deradicalisering).

De eerste route heeft als 'leitmotiv' dat jongeren geduwd worden: weg van de problemen van familie of buurt en vooral weg van het gebrek aan emotionele steun. Wat aantrekt is een surrogaat familie en autoriteiten die heldere antwoorden geven op de innerlijke onzekerheden. De-radicalisering komt op gang doordat de persoon genoeg krijgt van de haat en het geweld.

De tweede route gaat juist over aangetrokken worden door de extremistische ideologie. Deze jongeren zijn niet noodzakelijk 'kansarm'; velen van hen zijn intelligent en ambitieus en afkomstig uit een stabiele familiecontext. Een diep verlangen naar betekenis drijft hen; de strijd tegen onrecht wordt het doel in hun leven. De omgeving biedt geen opties hiervoor, dus zoeken ze de radicale beweging op. Ze deradicaliseren als ze het nut van geweld niet meer zien en de hypocrisie binnen de beweging niet meer trekken.

Een derde route betreft de passionate personalities. Waarvan de omgeving altijd zei 'dat is me er eentje...'. Dergelijke persoonlijkheden voelen zich aangetrokken tot extreme uitdagingen: een veeleisend dieet of spannende sport. Het alledaagse leven komt niet tegemoet aan hun krachtige verlangens. Als zij radicaliseren, gaan ze 'all the way', leren hele ideologische boeken uit het hoofd. De-radicalisering komt meestal als ze zijn uitgeraasd en zich gaan vervelen.

6 F. Buijs, Strijders van Eigen Bodem, Amsterdam 2016; K. van den Bos e.a., Waarom jongeren radicaliseren en sympathie krijgen voor terrorisme, Utrecht 2011; M. van San e.a., Idealen op drift, Utrecht 2010.

7 S. Sieckelinck \& M. de Winter (eds.), Formers and Families: Transitional journeys in and out of extremisms in the United Kingdom, Denmark and The Netherlands, Den Haag 2015. 
Om deze drie routes nóg beter te begrijpen is het nodig niet alleen naar deze psychosociale dimensie van processen van (de)radicalisering te kijken, maar ook naar de rol van meer existentiële en transcendente behoeften en legitimaties van het (extreme) handelen. Juist het begrip 'impliciete religie' maakt deze nadere duiding mogelijk:

1 In de eerste route gaan existentiële behoeften uit naar verhalen die orde scheppen in de chaos van het leven: absolute waarheidsclaims, helder onderscheid goed en kwaad. Er is een groot verlangen naar ergens bij horen, thuiskomen, eindelijk gezien en gehoord worden. Gezochte eenheidservaringen hebben vooral een sociaal karakter: één worden in de grote warme familie. Ook verhalen die de eigenwaarde stutten slaan aan: je maakt deel uit van het grotere geheel. De precieze inhoud doet er niet toe: dit zijn de types die met 'Islam voor Dummies' op jihadreis gaan. Het maakt hen niet minder gevaarlijk. Geweld krijgt, net als bij school-shooters, de betekenis van gerechtvaardigde wraak uit naam van alle vernederde broeders en zusters.

2 In de tweede route gaat het om de aantrekking door een waarachtig en inspirerend verhaal over de rechtvaardige wereld. Jihadisten op deze route leren de Koran uit hun hoofd en akkeren de ideologie helemaal door. De eenheidservaring is het opgaan in de utopie (met anderen of alleen). De rituelen zijn minder gericht op deel worden van een 'warm nest'. Veel belangrijker is het welslagen van de revolutie! Alleen een heilige oorlog kan alle obstakels naar de rechtvaardige wereld uit de weg ruimen. Voor het individu dat zich daarvoor opoffert betekent dit weliswaar een 'shortcut' naar het paradijs, maar het eigenlijke doel is bijdragen aan de verandering van de wereld.

3 In de derde route zullen de verhalen veel meer moeten stutten dan eigenwaarde: ze maken het toneel gereed voor de glansrijke hoofdrol van de uitverkoren superheld of juist dappere underdog. Die zich opoffert in een strijd die het uiterste vergt en daarmee eeuwige roem vergaart. Eindelijk zal de wereld inzien hoe bijzonder de persoon altijd al was.

Impliciete religie is zo gezien op verschillende manieren cruciaal voor radicalisering: als drijfveer, als vormgever én als legitimatie voor het handelen. Dit inzicht helpt om de schijntegenstelling te overstijgen die in het begin van het artikel werd benoemd, namelijk of de (expliciete) godsdienst/ideologie de belangrijkste drijfveer voor radicalisering is, óf de sociale context. Ik denk dat beide dimensies meespelen, en wel via hun interactie met impliciete religie. Expliciete godsdienst vult de inhoud van de impliciet religieuze verhalen, en sociale condities bepalen de urgentie van impliciet religieuze verlangens. Een toelichting.

In de eerste plaats: impliciet religieuze verlangens en behoeften bepalen hoe de expliciete religie (of ideologie) wordt gebruikt. Per radicaliseringsroute hebben mensen andere existentiële vragen en verlangens. Als oplossing halen ze aspecten uit bijvoorbeeld de islam, het communisme of het rechts-nationalistisch denken. Het zijn niet deze (oppervlakkig ingebrachte) teksten en praktijken die drijvend zijn voor het geweld dat uiteindelijk in naam ervan wordt uitgeoefend; dat zijn de onderliggende existentiële worstelingen. 
In de tweede plaats: sociale condities zijn van invloed op impliciet religieuze behoeften én op het aanbod dat daarin voorziet. Onderzoek verwerpt een directe correlatie tussen extremisme en factoren als armoede, opleidingsniveau en discriminatie. ${ }^{8}$ Maar ze kunnen er wel een vruchtbare voedingsbodem voor vormen. In het Formers and Families-onderzoek had twee derde van de families te maken met scheiding, afwezige vaders, gebrek aan emotionele steun, psychiatrische problemen, ziekte of dood. Daarnaast speelden bij een deel geweld en misbruik. ${ }^{9}$ Het is aannemelijk dat dergelijke omstandigheden existentiële worstelingen extra ingewikkeld en nijpend maken. Ook de begeleiding door ouders en anderen schiet juist in deze moeilijke omstandigheden eerder tekort.

Naast expliciete religieuze of ideologische leerstellingen en sociale condities speelt ook de kracht van extremistische rekruteurs een rol. Zij springen in de leemte van tekortschietende begeleiding van jongeren bij het vinden van een inhoudelijk antwoord op hun existentiële vragen en bij het vervullen van hun sociale behoeften. De rekruteurs wakkeren emoties aan en framen die in hun eigen narratief, zodat hun uitweg de enige goede lijkt (vergelijk hoe de tabaksindustrie reclame inzet om verhalen van vrijheid en stoerheid te verbinden met roken). De extremistische groep moedigt ook het doorsnijden van oude banden aan, waardoor de persoon steeds afhankelijker raakt. Vooral de angst wordt flink aangewakkerd: angst om de nieuwe familie te verliezen (route 1), het heilige doel niet te bereiken (route 2) of terug te moeten naar het kale leven als 'loser' (route 3). ${ }^{10}$ Deze onverdraaglijke existentiële angsten zetten zo'n dwingende logica in werking dat personen denken 'geen andere keus' te hebben dan geweld. ${ }^{11}$

Die keus hebben ze natuurlijk wel. Net als school-shooters zoeken extremisten het pad van geweld zelf op als oplossing voor hun innerlijke worstelingen. Een keuze die, in elk geval op de korte termijn, effectief uitpakt. Deradicalisering heeft dan ook geen enkele zin zonder alternatieven voor de functionaliteit van impliciete religie. De jongeren radicaliseren omdat ze - door de sociale context en/of hun persoonlijke opmaak - een grote behoefte hebben aan existentiële zekerheden, het opgaan in een spiritueel gemeenschapsgevoel of in de strijd voor een heilig doel. Je kunt hen de radicale oplossingen die ze vonden niet afnemen zonder iets in de plaats te stellen voor deze behoeften en verlangens. Sieckelinck stelt in zijn vervolgstudie dan ook voor dat we juist leren van rekruteurs. De strategie moet niet zijn deradicaliseren, maar juist re-radicaliseren: het winnen van 'hearts and minds' van jongeren door het bieden van oplossingen voor existentiële wor-

8 P. Gurski, The Threat from Within: Recognizing Al Qaeda-Inspired Radicalization and Terrorism in the West, New York 2015.

9 Vergelijkbare percentages blijken uit de Nederlandse casussen van jihadistische uitreis. Toch zijn niet allen sociaal-economisch kwetsbaar; sommigen handelen bijvoorbeeld uit oprechte woede over geopolitieke onrechtvaardigheden (route 2). Meestal beweegt een persoon in diverse routes tegelijk.

10 Zie ook de bijdrage van een voormalig 'lid' van de Hofstadgroep in Schuurman e.a., Structural influences on involvement in European homegrown jihadism: A case study, Den Haag 2016.

11 Dergelijke woorden staan letterlijk in de correspondentie van veel school-shooters. 
stelingen die even heldhaftig zijn, maar die niet een extremistische lading hebben. ${ }^{12}$

Het belangrijke punt is dat de werking van de impliciete religie centraal staat in de achtergrond van radicalisering. Expliciete godsdienst en sociale condities werken in op impliciete religie en zijn daarom eveneens belangrijk, maar alleen in afgeleide zin. Zoals we zagen in de drie routes naar extremisme kan radicalisering ook zonder expliciete godsdienst en ook zonder moeilijke sociale condities. Maar in alle gevallen spelen existentiële behoeften, transcendente ervaringen en sacrale rituelen een rol.

Het interessante is dat impliciete religie niet alleen speelt bij extremistische actie die zich expliciet beroept op godsdienst, maar bij álle vormen van extremisme. Bij jihadisme ontstaat hier de verwarring. Jihadisten nemen immers wel degelijk aspecten uit de mainstream islam over in hun narratieven. Het punt is dat de gevaarlijke werking niet uitgaat van de religie an sich, maar van de radicale manier van denken die zich de religie toe-eigent en als enige waarheid poneert. Deze manier van denken stoelt op:

a absolute waarheidsclaims: onbetwistbare verhalen over de werkelijkheid, een heldere en rechtvaardige ordening der dingen, geen ruimte voor nuance of twijfel;

b dichotomie vriend/vijand: helder onderscheid tussen de zuivere, superieure 'wij' en de kwaadaardige, inferieure 'zij';

c rechtvaardige strijd: de dreiging is enorm, de ondergang nabij. Er is geen andere keus dan vechten. Slachtoffers hebben hun rechten verspeeld, ze verdienen hun lot.

Wat mij nu verontrust, is dat ik juist deze elementen ook soms denk te herkennen in de discussie juist over de bestrijding van extremisme. Het absolute geloof in de eigen waarheid, het demoniseren van de ander, een manicheïstische wereld (dichotome wij/zij, goed/fout-voorstellingen) en de onbetwistbare noodzaak van harde strijd - deze en andere radicale noties keren vaak terug, vooral waar het gaat om het tegengaan van jihadisme en salafisme. Ik wil hier niemand specifiek op afrekenen; sterker nog, ik herken de redenaties soms ook bij mezelf. Het gaat om een radicale manier van redeneren die in de discussie sluipt. Daar schrik ik van, omdat ik ervan overtuigd ben dat een extremistische mindset nooit vanuit dezelfde radicale logica overwonnen kan worden.

Hierna onderzoek ik of het inderdaad zo is dat er een gelijkenis is in de logica van extremisten en sommige contra-extremistische redenaties. Wat betekent dit? Wat zijn de kwalijke gevolgen en wat kunnen we ervan leren?

\section{Impliciete religie en contra-extremisme}

Radicaal denken over contra-extremisme zegt te strijden uit naam van vrijheid, verlichting of democratie, maar verabsoluteert deze strijd. We herkennen dit denken op momenten dat we meegaan in de dichotome logica van wij/zij, goed/ 
slecht. Het absolute goede, dat zijn 'wij', omdat wij de juiste, meest verheven waarden hebben. Dit zijn waarden van democratie en rechtsstaat, geworteld in 'onze cultuur'. 'Onze' democratische waarden zijn universeel: ze gelden voor iedereen en iedereen kan ze omarmen. Het is een keuze. Niet iedereen van 'onze eigen groep' houdt zich er altijd aan, maar dat zijn oppervlakkige aberraties; onze kern is zuiver.

'Zij' verwerpen onze waarden en kiezen voor wezenlijk afwijkende, inferieure waarden. Ze doen dit uit onwetendheid of onwillendheid. In het eerste geval moeten ze inburgeren (zich 'bekeren'), in het tweede geval worden bestreden. In de kern zijn zij verdorven en zeer gevaarlijk. Ze bedreigen het democratisch collectief en alleen een keiharde aanpak kan de dreiging afwenden. De dreiging komt overigens zowel van buiten als van binnen. In het eerste geval gaat het om de 'echte ander' die niet is opgegroeid in 'onze' cultuur. Bij het tweede gaat het om 'afvalligen' uit de eigen gemeenschap die in hun naïviteit het gevaar niet zien of, erger nog, collaboreren met de vijand. Net als jihadisten de grootste afkeer hebben van moslims die hen niet accepteren, worden vanuit deze mindset de giftigste pijlen gericht op de 'softies', 'gutmenschen', 'cultuurrelativisten' en andere afvalligen uit de eigen groep.

Uiteraard wil ik hier niet het ideaal van democratie gelijkstellen aan extremistische idealen; waar het om gaat is dat de democratie vanuit een radicale wij-zijlogica wordt verdedigd. Deze manier van denken is verleidelijk, omdat ze, net als bij andere vormen van radicalisme, zoveel existentiële benefits heeft. De verhalen van zuiverheid en superioriteit herstellen gevoelens van trots. Ze genereren verbondenheid en identiteit (thuis in ons joods-christelijk, verlicht Nederland). Ze adresseren diepe angsten en motiveren het optreden tegen de als acuut beleefde dreiging. ${ }^{13}$ Een dergelijk radicaal antwoord op extremisme is functioneel en daarom ook zeer begrijpelijk. Maar als basis voor de strijd tegen terrorisme en extremisme is het niet waarachtig en buitengewoon ineffectief.

Het is niet waarachtig omdat het (a) niet is geïnteresseerd in de werkelijke dreiging. Dit klinkt bizar, omdat waar het radicale denken overheerst, het over bijna niets anders lijkt te gaan. Maar deze bekommernis leidt niet tot echte interesse in feiten of genuanceerde analyses. De uitkomst van analyse staat bij voorbaat vast: de dreiging is enorm, de vijand overal. Elk incident, hoe klein ook, is aanleiding om de noodklok te luiden. Alleen informatie die het vooropgestelde frame bevestigt, komt binnen.

Niet alleen de dreiging wordt niet uitgeplozen, er is ook (b) geen echte interesse in de daders. Enige nieuwsgierigheid naar drijfveren of dilemma's ontbreekt. Jihadisten (of salafisten) hoeven niet onderzocht te worden in hun veelzijdigheid, veranderlijkheid, deels op 'ons' lijkend/deels verschillend. Er is geen reden om de ander

13 Ook hier zijn de onderliggende processen te onderzoeken die ons drijven tot deze radicale manier van denken: Zijn we er meer toe geneigd in precaire sociale omstandigheden (route 1)? Gaat het om de behoefte aan een inspirerende droom of zijn extreme persoonlijkheden er meer vatbaar voor (route 2 of 3)? Ook kunnen de aspecten van impliciete religie worden uitgediept: Welke existentiële verlangens en angsten voeden deze radicale democratische narratieven? Welke transcendente ervaringen en rituelen zijn ermee verbonden? 
te leren kennen; de ander is al gekend in zijn inherente slechtheid. Een gesprek kan alleen maar stuiten op de muren van onwetendheid/onwillendheid van de ander. Als de ander zich constructief opstelt, moet dat wel een façade zijn. Common ground is uitgesloten; laat staan de mogelijkheid iets van de ander te leren.

Deze manier van denken hoeft niets te leren, omdat het ervan overtuigd is de waarheid (de superieure democratische kern) al in pacht te hebben. Maar de realiteit is dat dit radicale denken (c) in de kern niet draait om democratische waarden. Als dat zo was, dan zou de strijd voor die waarden op alle fronten gelijkelijk worden gevoerd. Maar dat is niet zo. Een van de signalen dat we in een radicale logica verstrikt raken, is als we gaan meten met twee maten. De noodklok luiden als salafisten vrouwonvriendelijke uitingen doen, maar stil zijn op alle andere fronten van vrouwenemancipatie. Aanslagen van moslims bij voorbaat zien als uiting van een verwerpelijke ideologie, maar die uit eigen kring (Brevik, Mair) als daden van gestoorde eenlingen die niets van doen hebben met onze (essentieel verlichte) cultuur. Heftig verontwaardigd zijn als andere leden van de 'andere groep' geen excuses aanbieden, onderwijl burgerslachtoffers bij westerse bombardementen wegwuivend als onvermijdelijke 'collateral damage' in een gerechtvaardigde strijd. Opkomen voor mensenrechten, maar bereid zijn de rand van de rechtsstaat op te zoeken waar het gaat om de bescherming van het eigen collectief.

Natuurlijk wil ik niet aanslagen of andere mistanden uit jihadistisch/salafistische kringen bagatelliseren. Ik probeer alleen te begrijpen waarom sommige issues zo veel meer lading (en geld) krijgen dan andere issues, die ook ernstig democratische waarden schenden. Ik vermoed dat dit samenhangt met de mate waarin existentiële angsten en identiteiten van het Nederlandse/westerse 'collectieve zelf' in het geding zijn. Dít is waar het in de kern om gaat, niet de waardenschending an sich. Dat verklaart ook de bereidheid om burger- en mensenrechten op te schorten van (vaak heel jonge) mensen die het pad van terrorisme opgaan. In de radicale logica zijn ze de absolute vijand: die heeft per definitie niet dezelfde rechten of zelfs menselijke waarde. Het effect van een keiharde aanpak op mensen en hun gemeenschappen wordt niet sterk gevoeld, omdat er nauwelijks identificatie met hen is. Ze zijn 'de ander' geworden.

Het is uitermate belangrijk om hiervan bewust te zijn, omdat hier de polarisatie begint. Als voor iemand andere angsten/identiteiten belangrijk zijn, dan ervaart die persoon een andere lading bij issues (bij iemand van Palestijnse afkomst komt een Israëlische geweldsdaad harder aan dan een aanslag in Frankrijk). Gebrek aan aandacht voor de eigen ervaring wordt dan gevoeld als 'meten met twee maten'. Het gehamer op democratische waarden (onderwijl zelf bereid deze op te schorten in ad-hocgevallen) wordt ervaren als diep hypocriet. Men redeneert: westerse landen leggen zout op elke slak van een moslim en ontkennen het kwaad dat systemisch in hun eigen geschiedenis, cultuur en handelen zit. En dan zijn ze verbaasd dat moslims hen haten! ${ }^{14}$ 
Maar gaat dit niet te ver? Bijna iedereen in de Nederlandse discussie respecteert toch democratische procedures? Dat is gelukkig waar. Waar ik aandacht voor vraag, zijn de onbewust uitsluitende mechanismen van het radicale denken over democratie en extremisme. In de radicale logica is de 'jihadist' of 'salafist' (maar ook 'de neonazi' en 'communist') niet een uniek, veranderlijk, kwetsbaar mens die onder omstandigheden een keuze maakte. Het radicalisme reduceert ze tot een eendimensionaal fantasiebeeld: een duivel of demon. En dit demoniseren leidt áltijd, bewust of onbewust, tot een agenda van zuivering en uitstoting van ongewenste feiten, ongewenste gedragingen en ongewenste personen.

Als inzet tegen extremisme en terrorisme is het radicale denken dan ook absoluut niet effectief. De uitsluiting van feiten en nuances leidt in de eerste plaats tot tunnelvisie. Als we de dreiging noch de dader werkelijk willen kennen, dan kunnen we die ook niet 'slim' bestrijden. Kansen op effectieve preventie worden gemist als de aanpak alleen maar 'keihard' mag zijn - niet als uitkomst van een afgewogen analyse (wat best een verdedigbare uitkomst kan zijn), maar bij voorbaat als enige optie om het absolute kwaad uit te roeien.

In de tweede plaats, het radicale denken drijft op polarisatie. De subtiele uitsluiting en ontmenselijking wordt gevoeld door mensen aan 'de andere kant': het kwetst, het maakt bang en het roept eenzelfde reactie uit. Zo belanden we in een wederzijds versterkende spiraal van angst, wantrouwen en haat.

Tot slot komt deze vraag in me op: zou het kunnen dat subtiele mechanismen van het radicale denken over democratie de 'war on terror' in stand houden? In de radicale logica heeft oorlog een functie om het collectief als 'goed' neer te zetten en het eigen 'zelf' te bekrachtigen in de superioriteit. Zou het kunnen dat onze eigen radicale denksporen misschien via onbewuste massapsychologische mechanismen helemaal niet gericht zijn op een einde aan de oorlog, omdat deze een samenhangende westerse democratische identiteit versterkt? ${ }^{15}$

Opnieuw, het gaat me niet om mensen of groepen als 'radicalen' weg te zetten, maar om alert zijn op een manier van denken die er makkelijk insluipt, zowel in het politieke als in het maatschappelijke debat, bij anderen, maar ook bij mezelf. Ik wil behoeden voor een makkelijke zelfgenoegzaamheid, een hypocriet rusten in eigen goedheid en gelijk. Omdat we dan geen moeite meer nemen om écht te kijken en écht goed te luisteren. In plaats daarvan gieten we de complexe wereld van dreiging en daders in de simpele mal van onze quasi-religieuze fantasieën. Het laatste wat we moeten doen is 're-radicaliseren' in deze richting! Een gedegen aanpak van extremisme moet zowel de onderliggende dynamieken van die bewegingen temperen, als ervoor waken hun logica te spiegelen. Maar hoe doen we dit? Hoe extremisme en terrorisme op een werkelijk waarachtige en effectieve manier te bestrijden?

15 Als school-shooters 'meaning-giving capacity' vinden in hun geweldsdaden (Pfeifer 2017, p. 118), welke zingeving biedt dan 'the war on terror'? 


\section{Democratische weerbaarheid}

Hoe kunnen burgers, politici, opiniemakers en professionals die met het thema bezig zijn vanuit een niet-radicale democratische houding tegenover contra-extremisme staan? Ik denk dat een van de kernelementen draait om het centrale imperatief dat de mens niet de andere mens tot middel mag reduceren. ${ }^{16}$ We gebruiken allemaal voortdurend mensen als middel, ook in contraterrorisme: 'jihadisten' om beleid op te maken, hun gemeenschap om mee te werken aan signalering, de exradicaal om lessen van te leren. Maar je mag nooit de mens volledig tot dat middel reduceren. Elk mens, ook je grootste vijand, heeft waarde in zichzelf. Het menszijn is een doel in zichzelf, een waarde die altijd gerespecteerd dient te worden. Echte democratische weerbaarheid neemt de menselijkheid als uitgangspunt. Maar hoe dan?

In de kern draait het wat mij betreft om het willen én kunnen volhouden van openheid. Openheid in de samenleving en openheid in jezelf - in je hoofd, in je hart en in je houding. ${ }^{17}$ Het eerste gaat over het hebben van een open mind: de wil en het vermogen om verschillende gezichtspunten te zien aan een situatie, de nieuwsgierigheid om verder te kijken, kritisch te reflecteren op jezelf en op de informatie die je tot je krijgt. In het burgerschapsonderwijs wordt het belang hiervan - ook in het kader van preventie van radicalisering - goed begrepen en onderwezen.

Wat veel minder aandacht krijgt is het open hart: de emotionele flexibiliteit om je in te leven in de situatie van een ander; de moed (coeur-courage) om het 'vreemde' tegemoet te treden. De intentie om vertrouwen op te bouwen met mensen, ook als ze anders lijken. Het vermogen om met compassie te kijken naar menselijke zwaktes, zowel die van jezelf als die van een ander. Maar ook het onderkennen van je eigen angsten en woede, en ermee kunnen omgaan zonder projecties op een absoluut schuldige ander. En cruciaal: in staat zijn je eigen innerlijke veiligheidsgevoel te voeden, zodat je minder afhankelijk wordt van de utopie dat alleen het verdelgen van de vijand dit creëert.

Niet alleen denken en voelen is belangrijk, essentieel is het vermogen om te relateren met mensen met een andere mening, achtergrond of identiteit. Het leren behoeften en irritaties zo te communiceren dat de ander zich niet aangevallen voelt en je krijgt wat je nodig hebt. Succesvol kunnen onderhandelen, waarbij je zowel je eigen belangen in het vizier houdt als de ander de ruimte geeft om je

16 Ik las Kant niet, maar had veel aan deze opnames van de politiek filosoof Michael Sandel: www. miriamrasch.nl/filosofie/2x-de-categorische-imperatief-van-kant-niet-liegen-en-niet-martelen/.

17 Ontleend aan een sociaal-psychologische studie naar het concept 'weerbaarheid'. Daar heet het meer academisch: 'cognitieve, emotionele en gedragsmatige indicatoren die betrekking hebben op bepaalde attitudes en vaardigheden'. L. Mann e.a., Indicatoren en manifestaties van weerbaarheid van de Nederlandse bevolking tegen extremistische boodschappen, Den Haag 2015. De notie van openheid als basis voor de democratische rechtsorde is natuurlijk ouder, bijv. in K. Popper, The Open Society and its Enemies, New York 1945, en H. Arendt, The Human Condition, Chicago 1958. 
tegemoet te komen. Naast open hoofd en hart gaat het ook om deze open houding. ${ }^{18}$

Anders dan de radicale vorm van contra-extremisme ons wil doen geloven, is er geen shortcut naar democratie, in de zin dat je er 'gewoon' voor moet kiezen. Echte democratische weerbaarheid vereist ingewikkelde cognitieve, emotionele en praktische vaardigheden. Dit betekent ook het toelaten van diversiteit, chaos en conflict - juist condities die radicalisering voeden. Daarom is het cruciaal dat we met die complexiteit leren omgaan. We kunnen het niet afwentelen op de jeugd of op nieuwkomers door alleen te focussen op burgerschapsonderwijs en inburgering. Een brede inzet is nodig vanuit overheid én samenleving om kritisch te kijken naar de uitsluitende mechanismen in het eigen denken en handelen, en om de vaardigheden te leren om openheid te bewaren. ${ }^{19}$

Wat we van extremisme kunnen leren is dat hier ook ruimte moet zijn voor impliciete religie - voor existentiële verhalen, transcendente ervaringen en zingevende rituelen. In onze geseculariseerde samenleving voelen velen zich niet meer comfortabel met het publiekelijk spreken over existentiële vragen van leven, dood en identiteit. In scholen, in het openbaar bestuur en op de arbeidsplek zijn we gericht op productiviteit, consumptie, veiligheid en entertainment. We raken de vaardigheden kwijt om met de 'daunting facts of life' om te gaan. Als we ons publieke domein spiritueel laten verschralen, dan mag de kracht van radicale ideologieën niet verbazen. ${ }^{20}$

De opgave van onze tijd is om nieuwe vormen van impliciete religie uit te vinden die helpen bij democratische weerbaarheid: nieuwe existentiële narratieven rondom openheid en menselijkheid, transcendente ervaringen die de huidige fragmentering en polarisatie overstijgen, en heilige rituelen van verbinding en herstel na harde actie.

Hier ligt een rol voor theologen en geestelijk begeleiders van diverse stromingen. Maar dan wel op de open manier die past bij de democratie: een twijfelende geest, een dapper hart en bekwame interactie. Helaas gaat georganiseerde religie, zeker in fundamentalistische vorm, vaak gepaard met dezelfde sluitende beweging van politieke radicalisering: de waarheid wordt verabsoluteerd, identificaties worden exclusief, de 'ander' wordt vermeden. Het is daarom zaak altijd kritisch te kijken welke religieuze partners worden betrokken in de strijd tegen radicalisering.

18 Methoden die deze vaardigheden voeden zijn bijv. mediatie, geweldloze communicatie, deep democracy, intercultureel vakmanschap, vreedzame school, public mediation enz. Maar ook films, literatuur en toneel slagen er vaak beter in nuances te vangen dan wetenschappelijke analyses. Het zou mooi zijn om dergelijke methoden meer te betrekken bij de inzet tegen radicalisering.

19 Zie voor competenties van democratisch burgerschap: H.R. van Gunsteren e.a., Eigentijds Burgerschap, Den Haag 1992.

20 Waarom is de sociale orde niet ingestort na 'de dood van God'? De religiositeit van veiligheidsvraagstukken en contra-terrorisme in het bijzonder heeft er iets mee te maken; H. Boutellier, Het Seculiere Experiment, Utrecht 2015. 
Gelukkig zijn er genoeg voorbeelden van wijsheid, moed en doortastendheid die polarisatie en radicalisering wel vanuit openheid weerstand bieden. ${ }^{21}$

Maar spiritueel leiderschap hoeft niet vanuit de expliciete religie te komen. Elke dag zijn er talloze moeders en vaders, jongerenwerkers en wijkagenten, rechters en medewerkers van inlichtingendiensten die staan voor een open manier van leven en samenleven. In menselijke verbondenheid en met respect voor de krachten die ons doen neigen naar compassie, moed en rechtvaardigheid. Zonder grote woorden als 'democratische weerbaarheid' in de mond te nemen, brengen zij open hart, hoofd en houding in de praktijk. Zonder hen zou de democratische cultuur morgen instorten. ${ }^{22}$

Ook bij de overheid gaat gelukkig veel goed. Er is steeds meer oog voor de menselijke (psychische en verstandelijke) beperkingen van daders van geweld, maar ook voor de rechten en het welzijn van slachtoffers. Er zijn organisaties die ouders, gemeenten en professionals adviseren bij het omgaan met de nuances van extremisme, zoals het Platform-JEP voor het jeugddomein.

Waar dergelijke initiatieven tegen aanlopen is de aantijging dat ze 'soft' zijn. Wat, zo rijst de vraag, hebben we aan 'menselijkheid' en 'openheid' in de strijd tegen krachten die deze kwaliteiten letterlijk willen opblazen? Hoe weerbaar is die open houding eigenlijk? Goede vragen, die verdieping verdienen. Hier volgt een aanzet.

\section{'The hard approach and the even harder approach'}

De hiervoor gestelde vragen verwijzen naar wat ook wel heet de machiavellian moment: de omstandigheid dat de orde dusdanig wordt bedreigd dat meedogenloos handelen gerechtvaardigd is. ${ }^{23}$ Deze momenten zijn er bij contra-terrorisme regelmatig. Militairen moeten hun empathie uitschakelen om te bombarderen. ${ }^{24}$ Er is een Dienst Speciale Interventies (DSI) die hardhandig mag optreden bij terroristische dreiging. Vergaande preventieve antiterrorisme wetten worden opgesteld voor de veiligheid.

Dergelijke 'machiavellian moments' gaan onvermijdelijk gepaard met een zekere sluiting van geest en hart. Juist daarom is het ontzettend belangrijk om ze te omringen met extra waarborgen om zo snel mogelijk de openheid en menselijkheid (de heilige orde van de democratie) weer te herstellen.

Waar het gaat om de open mind moeten dergelijke speciale interventies altijd op precieze analyse berusten, nooit op een vaag vijandsbeeld. Ze moeten uitgaan van

21 Ik denk hier aan de hand die rabbijn Lody uitstak naar bedreigde salafistische moskeeën en de vele goede lokale interreligieuze initiatieven. Beatrice de Graaf gaat in Heilige Strijd (2017) in op een open christelijk perspectief op de strijd tegen terrorisme.

22 Zie voor een uitweiding over de onmisbare voorwaarden voor de open samenleving en democratische rechtsstaat: AIVD, Van Dawa tot Jihad, Den Haag 2004.

23 J. Pocock, The Machiavellian Moment, Princeton 1975.

24 Een weergave van zo'n moment is de film Eye in the Sky over een drone-aanval tegen Boko Haram waar een kind bij betrokken is. De film brengt indringend het verschil in beeld tussen de professionals en politici die daar instrumentalistisch in staan en diegenen die een open hart weten te behouden. Hoe soldaten met dergelijke dilemma's omgaan, is ook te zien in de mooie documentaire Kijken in de Ziel van... de militair, 2017. 
algemene principes en onafhankelijk worden getoetst. Bij schending van principes zijn herstellende rituelen nodig (zoals de schadevergoeding na een onterecht gebleken inval van de DSI in 2012 bij een vermoede jihadistische cel in Rotterdam).

Voor dit 'open hoofd' is relatief veel plaats in de discussie over contra-terrorisme. Veel minder aandacht is er voor het hart. Te vaak verschuilen politici en professionals zich achter procedurele rechtvaardigheid ('de dreiging maakte geen andere keuze mogelijk; alles ging volgens protocol'). Mensen ervaren dit als harteloos en keren zich af van het systeem. Waar échte democratische weerbaarheid verschilt van radicale denkwijzen is niet dat het softe actie voorstaat. Het verschil is dat er altijd ruimte is voor het hart: voor morele dilemma's, voor de pijn van tragische keuzes, voor de menselijkheid van zowel slachtoffers als daders, maar ook van de ambtenaar, militair of rechter die de harde interventie moet uitvoeren. Sterker nog, juist openheid is essentieel voor effectief strijden. Zoals elke vechtsporter weet: je moet oefenen in een open, rustige, alerte houding om de klappen te zien aankomen en je tegenstander goed te raken.

Leven in openheid is niet eenvoudig. In Noord-Ierland hoorde ik de politie in dit kader spreken van 'the hard approach and the éven harder approach'. Echte openheid betekent een continu balanceren tussen gezichtspunten, belangen en waarden. Het is precies dit balanceren dat radicalisme niet kan en niet wil. Zoals Pfeifer over school-shooters schrijft: ze willen niet balanceren, daarom blazen ze de boel op. ${ }^{25}$

De radicale sluiting van extremisme is alleen te counteren met radicale openheid. Als we echt een weerbare democratie willen, dan moeten we - als burger, wetenschapper, politicus of professional - bereid én in staat zijn tot een open houding. Competent balanceren tussen inleving en begrenzing, het 'niet zeker weten' maar er toch voor staan, de ander verafschuwen maar toch diens menselijkheid erkennen - dat is de moeilijkste maar ook meest waardige politieke strijd die er is.

Moralisme gaat daarbij niet helpen; kennis van impliciete religie wel. Ik vermoed dat radicalisering veel te maken heeft met angst en woede door een pijnlijke afsluiting van liefde en zinvolle betekenis. Het radicale denken verschijnt als oplossing voor deze pijn door waarheden te verabsoluteren en harten dicht te timmeren. In deze tijden van sociale opwarming moeten we op zoek naar alternatieve antwoorden op impliciete religieuze vragen en verlangens. Dit is een opgave waar ook godsdienstwetenschappers en andere geïnteresseerden in religie, recht en beleid hard bij nodig zijn. 